\title{
PERAN TENAGA KERJA WANITA DALAM KEGIATAN USAHATANI KACANG TANAH DI DESA KANONANG, KECAMATAN KAWANGKOAN BARAT
}

\author{
Pingkan Assa \\ Ribka M. Kumaat \\ Paulus A. Pangemanan
}

\begin{abstract}
ABSRACT
The aim of this research is to know the role of women farmer in peanut farming activity. This research was carried out for two months from May until June 2017. Samples were taken as many as 20 respondents (Survey Sampling), each village was taken 5 respondents: on Kanonang 1 Village, Kanonang 2 Village, Kanonang 4 Village, and Kanonang 5 Village at Kawangkoan Barat District. The data collected in this study through interviews and presented descriptively in tabular form. The role of female laborers is seen from the peak time of women work in peanut farming is highest in weeding activity, second harvest, third post harvest, fourth marketing, fifth planting, six tillage, seventh seed selection. Women are not play role on fertilization and pest control of diseases.
\end{abstract}

Keywords: role, labor, female, farm, peanut, Village of Kanonang 1-5, West Kawangkoan District

\begin{abstract}
ABSTRAK
Penelitian bertujuan untuk mengetahui peranan wanita tani dalam kegiatan usahatani kacang tanah. Penelitian ini di laksanakan selama dua bulan yaitu dari bulan Mei sampai Juni tahun 2017. Sampel diambil sebanyak 20 responden yaitu setiap desa diambil 5 responden di Desa Kanonang 1, Desa Kanonang 2, Desa Kanonang 4, dan Desa Kanonang 5 di Kecamatan Kawangkoan Barat. Data yang dikumpulkan pada penelitian ini disajikan secara deskriptif dalam bentuk tabel. Peran tenaga kerja wanita dilihat dari curahan waktu kerja wanita dalam usahatani kacang tanah yang tertinggi yaitu pada kegiatan penyiangan, kedua panen, ketiga pasca panen, keempat pemasaran, kelima penanaman, keenam pengolahan tanah, dan ketujuh seleksi benih. Wanita tidak berperan pada pemupukan dan pengendalian hama.
\end{abstract}

Kata kunci: peran, tenaga kerja, wanita, usaha tani, kacang tanah, Desa Kanonang, Kecamatan Kawangkoan Barat 


\section{PENDAHULUAN}

\section{Latar Belakang}

Sektor pertanian di Indonesia mempunyai peranan yang sangat penting dalam perkembangan pembangunan yaitu sebagai sumber kehidupan dan pendapatan petani dalam keluarga. Sektor pertanian apabila dikembangkan secara terus-menerus akan membawa dampak terhadap persoalan ketenagakerjaan terutama tenaga kerja wanita. Hal ini terlihat dari sektor pertanian terhadap penyediaan lapangan kerja, penyediaan pangan, dan penyumbangan devisa negara melalui ekspor. Tingginya angka tenaga kerja yang diserap oleh sektor pertanian terjadi karena adanya program penyediaan infrastruktur dan perluasan areal serta pemberdayaan bagi petani yang dilaksanakan oleh pemerintah. (Kompas, 2011). Wanita sebagai salah satu sumber daya manusia di pasar tenaga kerja terutama di Indonesia mempunyai kontribusi besar, dalam arti bahwa jumlah wanita yang menawarkan diri untuk bekerja cukup besar. Partisipasi kaum wanita dalam berbagai kegiatan ekonomi telah meningkat secara berarti pada semua sektor, terutama di kalangan wanita pekerja muda dan di sektor modern. Tidak saja pada keseluruhan pasar kerja tetapi terlebih di sektor formal telah terjadi proses feminisasi dan status wanita pekerja telah membaik. Perkembangan demikian terjadi pada periode pertumbuhan ekonomi dan perubahan struktural yang cepat, pasar kerja umumnya telah membaik (Zannatos, 2004). Saat ini, peran wanita telah bergeser dari peran tradisional menjadi modern. Dari hanya memiliki peran tradisional untuk melahirkan anak (reproduksi) dan mengurus rumah tangga, kini wanita memiliki peran social dimana dapat berkarir dalam bidang kesehatan, ekonomi, sosial, maupun politik dengan didukung pendidikan yang tinggi. Secara tradisional, peran wanita seolah dibatasi dan ditempatkan dalam posisi pasif yaitu wanita hanyalah pendukung karir suami. Peran wanita yang terbatas pada peran reproduksi dan mengurus rumah tangga membuat wanita identik dengan pengabdian kepada suami dan anak. Sementara wanita modern dituntut untuk berpendidikan tinggi, berperan aktif, dan kritis (Health Woman, 2008). Fenomena wanita bekerja telah menjadi hal yang menarik untuk dikaji, lebih-lebih wanita yang tinggal di pedesaan. Keterlibatan mereka bekerja sebagian besar dikarenakan tuntukan ekonomi. Kondisi perekonomian keluarga yang lemah dan serba kekurangan memaksa wanita ikut bekerja membantu suaminya dalam rangka mendapatkan penghasilan tambahan. Mengingat mayoritas mata pencaharian penduduk desa adalah bertani maka kebanyakan wanita ikut bekerja membantu suaminya pada akhirnya bekerja pula dibidang pertanian (Komariyah, 2003).

Tanaman kacang tanah memiliki peranan yang sangat penting bagi petani yang mengusahakannya di Desa Kanonang. Usahatani kacang tanah di Desa ini telah dilakukan sejak lama dan turun- temurun tujuannya adalah sebagai sumber pendapatan utama bagi petani di Desa tersebut. Hal ini dikarenakan tanaman kacang tanah mampu memberikan pendapatan yang relatif baik dibandingkan dengan pendapatan yang diperoleh dari cabang usahatani yang lainnya, karena harga jual kacang tanah mentah maupun kering yang di terima petani rata-rata relatif tinggi. Wanita tani memerankan peranan penting pada kegiatan usahatani untuk meningkatkan produksi kacang tanah. Kegiatan usahatani yang dilakukan wanita tani dipengaruhi oleh curahan waktu kerja. curahan waktu kerja wanita tani dalam kegiatan yang produktif banyak tergantung pada faktor sosial ekonomi dan keadaan keluarganya. Faktorfaktor sosial ekonomi yang berpengaruh pada curahan waktu kerja wanita tani adalah usia, jumlah tanggungan keluarga, tingkat upah, luas lahan, status perkawinan, tingkat pendidikan, dan tingkat pengalaman (Sukesi, 2002). Desa kanonang yang masuk dalam Kecamatan Kawangkoan barat terdiri dari empat desa kanonang, yaitu desa kanonang satu, desa kenonang dua, desa kanonang empat, dan desa kanonang lima. Dengan demikian perlunya dilakukan penelitian, mengenai peran tenaga kerja wanita pada usaha tani kacang tanah di Desa Kanonang Kecamatan Kawangkoan. 


\section{Perumusan Masalah}

Berdasarkan latar belakang tersebut, maka perumusan masalah adalah bagaimana peran wanita dalam usahatani kacang tanah di desa kanonang kecamatan Kawangkoan Barat

\section{Tujuan Penelitian}

Berdasarkan perumusan masalah, maka yang menjadi tujuan penelitian adalah untuk mengetahui peranan wanita tani dalam kegiatan usahatani kacang tanah.

\section{Manfaat Penelitian}

1. Bagi pemerintah penelitian ini dapat dijadikan sebagai bahan informasi pengambilan kebijakan upaya menyusun dan meningkatkan pembangunan subsektor pertanian dalam hal ini sektor pertanian khususnya para petani kacang tanah.

2. Bagi produsen baik wanita tani maupun para petani kacang tanah, penelitian ini dapat dijadikan sebagai informasi yang dapat membantu untuk meningkatkan produksifitas dalam usahatani kacang tanah.

3. Bagi peneliti lain, penelitian ini dapat dijadikan sebagai sumbangan pemikiran dan informasi dalam penyusunan penelitian selanjutnya

\section{METODOLOGI PENELITIAN}

\section{Waktu Dan Tempat Penelitian}

Penelitian ini di laksanakan selama empat bulan yaitu dari bulan Maret 2017 sampai Juni tahun 2017 mulai dari persiapan sampai penyusunan laporan penelitian. Tempat penelitian adalah di desa Kanonang yang ada di Kecamatan Kawangkoan Barat yaitu yang terdiri dari desa kanonang 1, desa kanonang 2, desa kanonang 4, dan desa kanonang 5.

\section{Metode pengumpulan data}

Penelitian ini menggunakan data primer dan data sekunder. Data primer diperoleh melalui wawancara langsung pada wanita tani kacang tanah tentang pembibitan, pengolahan tanah, penanaman, penyiangan, pengendalian hama dan penyakit, pemupukan, panen dan pasca panen, dengan menggunakan daftar pertanyaan yang telah disiapkan berupa kuisoner, sedangkan data sekunder diperoleh dari kantor Desa Kanonang Kecamatan Kawangkoan Bawat serta instansi yang terkait dalam penelitian ini.

\section{Metode Pengambilan Sampel}

Populasi dalam penelitian ini yaitu semua wanita tani yang sudah berkeluarga dan bekerja pada usahatani kacang tanah. Pengambilan sampel menggunakan metode (purposive sampling), yaitu memilih wanita tani yang bekerja pada usahatani kacang tanah. Sampel diambil sebanyak 20 responden secara (Survey Sampling) yaitu setiap desa diambil 5 responden yang ada di kanonang 1, desa kanonang 2, desa kanonang 4, dan desa kanonang 5 di Kecamatan Kawangkoan Barat.

\section{Konsep Pengukuran Variabel}

Adapun variabel yang akan di teliti adalah peran wanita dalam usahatani kacang tanah yang diukur dengan curahan waktu kerja wanita dalam setiap jenis kegiatan, kegiatan tersebut meliputi :

1. Seleksi Benih (jam/hari)

2. Pengolahan tanah (jam/hari)

3. Penanaman (jam/hari)

4. Penyiangan (jam/hari)

5. Pengendalian hama penyakit (jam/hari)

6. Pemupukan (jam/hari)

7. Panen (jam/hari)

8. Pasca Panen (Jam/hari)

9. Pemasaran (Jam/Hari)

\section{Metode Analisi Data}

Data yang dikumpulkan pada penelitian ini akan disusun secara deskriptif. Dimana data yang terkumpul akan disajikan dalam bentuk Tabel.

\section{HASIL DAN PEMBAHASAN}

\section{Deskripsi Lokasi Penelitan}

\section{Keadaan Geografis Lokasi Penelitian}

Kawangkoan Barat adalah salah satu Kecamatan di Kabupaten Minahasa Provinsi Sulawesi Utara. Ibukota Kecamatan 
Kawangkoan Barat adalah desa Kayuuwi, berjarak sekitar $28 \mathrm{~km}$ dari Tondano, ibukota Kabupaten Minahasa. Adapun batas-batasnya adalah sebagai berikut :

a. Sebelah Utara dengan Kecamatan Sonder dan Kawangkoan Utara

b. Sebelah Timur dengan Kecamatan Kawangkoan

c. Sebelah Selatan dengan Kecamatan Tompaso

d. sebelah Barat dengan Kecamatan Tareran Kabupaten Minahasa Selatan

\section{Keadaan Penduduk Lokasi Penelitian}

keadaan penduduk pada lokasi penelitian akan dapat mempengaruhi jumlah pekerjaan yang akan dipilih atau akan mempengaruhi pilihan pekerjaan pada wanita tani. Dalam lokasi penelitian jumlah penduduk dapat dilihat pada Tabel 1. Tabel 1. Menunjukan bahwa penduduk terbanyak terdapat pada desa kanonang satu dengan jumlah penduduk sebesar 741 penduduk dari total penduduk desa kanonang sebesar 2732 penduduk dengan persentase penduduk sebesar $27,12 \%$ dari total penduduk desa kanonang.

\section{Karakteristik Responden}

\section{Umur}

Umur yang produktif pada usia 16 tahun sampai 60 tahun, jika diatas 60 tahun maka usia fisik petani semakin menurun dan produktifitas dalam usahatani bisa berkurang. Menurut penelitian yang sudah dilakukan umur responden dapat dilihat pada Tabel 2. Hasil penelitian menunjukan bahwa kelompok umur 35 sampai 50 memiliki jumlah responden terbanyak sebesar 12 responden dengan persentase $60 \%$ dan dapat menunjukan bahwa sebagian besar responden dapat dikatakan masih dalam usia produktif.

\section{Tingkat pendidikan}

Tingkat pendidikan sangat penting untuk wanita dalam usahatani kacang tanah, karena tingkat pendidikan akan mempengaruhi keputusan wanita dalam bekerja dan mengurus pekerjaan dalam rumah tangga. Berdasarkan penelitian tingkat pendidikan wanita tani dapat dilihat pada Tabel 3. Hasil penelitian menunjukan bahwa tingkat pendidikan petani di desa kanonang, memiliki tingkat pendidikan terbanyak yaitu $45 \%$ pada tingkat pendidikan Sekolah Dasar (SD), sedangkan 35\% berada pada tingkat pendidikan SMP dan pada tingkat pendidikan SMA hanya mencapi $20 \%$.

\section{Peran Tenaga Kerja Wanita Dalam Usahatani Kacang Tanah di Desa Kanonang Kecamatan Kawangkoan Barat}

Dalam usahatani, peran tenaga kerja perempuan sangat penting dalam meningkatkan jumlah kebutuhan tenaga kerja yang dapat dikatakan tenaga kerja di bidang pertanian mayoritas dilakukan oleh pekerja laki laki karena usahatani merupakan pekerjaan yang berat untuk tubuh. Peran wanita dalam usahatani biasanya terletak pada bagian yang mudah sehingga perempuan dapat ikut berperan dalam usahatani. Peran wanita dalam hasil penelitian pada Tabel 4 terdiri dari kegiatan seleksi benih, pengolahan tanah, penanaman, penyiangan, panen, pasca panen, pemasaran. Dan dalam pengambilan dalam satu periode, pada pengendalian hama dan penyakit dan pemupukan di lakukan oleh laki - laki pada usahatani kacang tanah.

\section{Kegiatan Seleksi Beni}

Dalam kegiatan seleksi benih usahatani kacang tanah, dilakukan dengan cara memilih benih yang dari kacang yang sudah dijemur yang mudah dikupas dan cukup besar benihnya. Dalam penelitian ini dilihat bagaimana peran wanita dalam kegiatan seleksi benih yang dilihat dari jumlah wanita tani yang ikut berperan serta jam yang dicurahkan dalam kegiatan tersebut. Pada tabel 4 menunjukan persentase dan jumlah waktu kerja dalam kegiatan seleksi benih. Dalam penelitian pada kegiatan seleksi benih dalam satu periode tanam, wanitab erperan dalam kegiatan seleksi benih dengan jumlah jam yang dicurahkan sebesar 60 jam dengan persentase jam $2,65 \%$ dari total jam kerja pada usahatani kacang tanah dan rata - rata 3 jam per responden pada kegiatan seleksi benih kacang tanah. 


\section{Kegiatan Pengolahan Tanah}

Dalam kegiatan pengolahan tanah kacang tanah, dilakukan dengan cara membersikan dahulu tanah dari gulma yaitu menyemprot rumput dan menunggu selama dua minggu untuk melihat sudah mulai tumbuh rumput dan akan segera membuat pembedengan. Dalam penelitian bertujuan untuk melihat peran wanita tani dalam pengolahan tanah kacang tanah yang dilihat dari jumlah wanita tani yang ikut berperan dan jumlah waktu dalam usahatani kacang tanah. Tabel 4 menunjukan jumlah dan presentase waktu kerja wanita dalam kegiatan pengolahan tanah. Dalam penelitian pada kegiatan pengolahan tanah dalam satu periode tanam, wanita berperan dalam kegiatan pengolahan tanah dengan jumlah jam yang dicurahkan sebesar 88 jam dengan persentase sebesar $3,88 \%$ jam dan rata - rata jam per responden sebesar 4,4 jam pada kegiatan pengolahan tanah kacang tanah.

\section{Kegiatan penanaman}

Dalam kegiatan penanaman kacang tanah, dilakukan dengan cara membuat lubang pada bedeng dengan kedalaman lubang $4 \mathrm{~cm}$ sampai $5 \mathrm{~cm}$, dimasukan 2 sampai 3 benih dengan jarak $30 \mathrm{~cm}$. dalam penelitian ini bertujuan untuk melihat peran wanita dalam kegiatan penanaman, yang dilihat dari jumlah wanita tani yang ikut berperan dan jumlah waktu dalam usahtani kacang tanah. Tabel 4 menunjukan jumlah dan persentase waktu kerja wanita dalam kegiatan penanaman. Dalam penelitian pada kegiatan penanaman dalam satu periode tanam, wanita berperan dalam kegiatan penanaman dengan jumlah jam yang dicurahkan sebesar 108 jam dengan persentase jam sebesar $4,76 \%$ dan rata - rata 5,4 jam per responden pada kegiatan penanaman kacang tanah.

\section{Kegiatan penyiangan}

Dalam kegiatan penyiangan usahatani kacang tanah, dilakukan dengan cara mencangkul tanaman liar atau gulma supaya tidak tercampur dengan gulma, sepaya hasil kacang tanah cukup baik yaitu tidak rusak dan jumlahnya banyak. Dalam penelitian ini bertujuan untuk melihat peran wanita dalam kegiatan penyiangan, yang dilihat dari jumlah wanita tani yang ikut berperan dan jumlah waktu dalam usahtani kacang tanah. Tabel 4 menunjukan jumlah dan persentase waktu kerja wanita dalam kegiatan penanaman. Dalam penelitian pada kegiatan penyiangan dalam satu periode, wanita berperan dalam kegiatan penyiangan dengan jumlah jam yang dicurahkan sebesar 940 jam dengan persentase jam sebesar $41,45 \%$ dan rata rata sebesar 47 jam per responden pada kegiatan penyiangan kacang tanah. ini dikarenakan pada kegiatan penyiangan cukup mudah dilakukan yaitu hanya mencabut rumput yang ada di sekitar atau ditengah tengah tanaman, akan tetapi kegiatan penyiangan cukup melelahkan jadi kegiatan penyiangan banyak dilakukan oleh buruh tani yaitu wanita tani dikarenakan desa kanonang memiliki tenaga kerja wanita dalam usatani kacang tanah yang merupakan mayoritas buruh tani.

\section{Kegiatan pengendalian hama dan penyakit}

Dalam kegiatan pengendalian hama dan penyakit dalam usahatani kacang tanah dilakukan dengan cara menyemprot pestisida. Dalam penelitian ini bertujuan untuk melihat peran wanita dalam kegiatan pengendalian hama dan penyakit, yang dilihat dari jumlah wanita tani yang ikut berperan dan jumlah waktu dalam usahtani kacang tanah. Tabel 4 menunjukan jumlah dan persentase waktu kerja wanita dalam kegiatan pengendalian hama dan penyakit. Dalam penelitian pada kegiatan pengendalian hama dan penyakit dalam satu periode, wanita tidak berperan dalam kegiatan pengendalian hama penyakit dikarenakan kegiatan yang dilakukan cukup berat disebabkan penyemprotan harus dipikul alat penyemprot dan itu cukup berat dan berbahaya untuk wanita tani.

\section{Kegiatan pemupukan}

Dalam kegiatan pemupukan dilakukan dengan cara menyemprotkan pupuk cair untuk menyuburkan tanaman yaitu menunggu dengan menunggu waktu biasanya 10 hari dari kegiatan penanaman benih kacang tanah. Dalam penelitian ini bertujuan untuk melihat peran wanita dalam kegiatan pemupukan, yang dilihat 
dari jumlah wanita tani yang ikut berperan dan jumlah waktu dalam usahtani kacang tanah. Tabel 4 menunjukan jumlah dan persentase waktu kerja wanita dalam kegiatan pemupukan. Dalam penelitian pada kegiatan pemupukan dalam satu periode tanam, wanita tidak berperan dalam kegiatan pemupukan disebabkan kegiatan pemupukan sudah biasa dilakukan oleh laki - laki, dan juga kegiatan pemupukan cukup sulit dikarenakan alat pupuk tersebut harus dipikul dan cukup berat untuk wanita dalam kegiatan pemupukan usahatani kacang tanah.

\section{Kegiatan panen}

Dalam kegiatan panen dilakukan dengan cara menunggu 100 sampai 115 hari dari waktu penanaman dan melihat daun jika sudah kuning dan mulai rontok daunnya maka kacang tanah sudah layak di panen, kegiatan panen yaitu mencabut tanaman, memisahkan tanaman dengan kacang, dibersihkan lalu dilakukan penyimpanan. Dalam penelitian ini bertujuan untuk melihat peran wanita dalam kegiatan panen, yang dilihat dari jumlah wanita tani yang ikut berperan dan jumlah waktu dalam usahtani kacang tanah. Tabel 4 menunjukan jumlah dan persentase waktu kerja wanita dalam kegiatan panen. Dalam penelitian pada kegiatan panen dalam satu periode tanam, wanita berperan dalam kegiatan panen dengan jumlah jam yang dicurahkan sebesar 380 jam dengan persentase jam sebesar $16,75 \%$ dan rata - rata jam sebesar 19 jam per responden dalam kegiatan panen usahatani kacang tanah.

\section{Kegiatan pasca panen}

Dalam kegiatan pasca panen dilakukan dengan cara penyortiran kacang yaitu melihat kacang yang baik dan kacang yang rusak atau tidak layak dibuang, kemudian dilakukan penjemuran bertujuan untuk mengurangi kadar air yang ada dalam kacang tanah sehingga akan membuat kacang tanah tahan lama. Dalam penelitian ini bertujuan untuk melihat peran wanita dalam kegiatan pasca panen, yang dilihat dari jumlah wanita tani yang ikut berperan dan jumlah waktu dalam usahtani kacang tanah. Tabel 4 menunjukan jumlah dan persentase waktu kerja wanita dalam kegiatan pasca panen.
Dalam penelitian pada kegiatan pasca panen dalam satu periode tanam, wanita berperan dalam kegiatan pasca panen dengan jumlah jam yang dicurahkan sebesar 356 jam dengan persentase jam sebesar $15,70 \%$ dan rata - rata jam per responden sebesar 17,8 dalam kegiatan pasca panen usahatani kacang tanah.

\section{Kegiatan pemasaran}

Dalam kegiatan pemasaran dilakukan dengan cara menjual hasil usahatani kacang tanah, biasanya kacang yang sudah di sangrai atau juga kacang yang sudah dipisahkan dari kulitnya, lalu dijual kepasar oleh wanita. Dalam penelitian ini bertujuan untuk melihat peran wanita dalam kegiatan pemasaran, yang dilihat dari jumlah wanita tani yang ikut berperan dan jumlah waktu dalam usahtani kacang tanah. Tabel 4 menunjukan jumlah dan persentase waktu kerja wanita dalam kegiatan pemasaran kacang tanah. Dalam penelitian pada kegiatan pamasaran dalam satu periode, wanita berperan dalam kegiatan pemasaran dengan jumlah jam yang dicurahkan sebesar 336 jam dengan persentase jam sebesar 14,81 jam dan rata - rata jam per responden sebesar 16,8 dalam kegiatan pemasaran usahatani kacang tanah.

\section{Kegiatan Wanita Tani Di Luar Usahatani}

Dalam kegiatan wanita dalam luar usahatani tidak terpisahkan dari kegiatan kegiatan mengurus rumah, memasak, membuat kopi dan mengurus anak. Walaupun wanita juga berperan dalam usahatani untuk membantu perekonomian keluarga, wanita juga perlu memperhatikan urusan rumah tangga. Dalam penelitian ini kegiatan luar usahatani, 20 responden pada pagi dan sore hari melakukan kegiatan memasak, membersihkan rumah, mengurus anak, menyiapkan kopi atau teh dengan rata rata 3,6 jam per hari dengan total jam 73 jam dalam per hari. dan pada siang hari jika tidak bekerja, wanita melakukan kegiatan sosial seperti pencarian dana gereja, istirahat tidur siang, melakukan keperluan lainnya seperti mengurus berkas2 seperti KTP atau kepentingan lainnya, dan menghadiri acara seperti menghadiri duka tetangga, jika terjadi duka pada tetangga, masyarakat sekitar tersebut tidak bekerja dalam satu hari. 
Tabel 1. Jumlah Penduduk dan Presentasi

\begin{tabular}{ccccccc}
\hline \multirow{2}{*}{ Nama Desa } & \multicolumn{3}{c}{ Jumlah Penduduk } & \multicolumn{3}{c}{ Persentase } \\
\cline { 2 - 7 } & Laki - Laki & Perempuan & Total & Laki - Laki & Perempuan & Total \\
\hline Kanonang 1 & 390 & 351 & 741 & 28,12 & 26,10 & 27,12 \\
Kanonang 2 & 345 & 363 & 708 & 24,87 & 26,99 & 25,92 \\
Kanonang 4 & 340 & 318 & 658 & 24,51 & 23,64 & 24,08 \\
Kanonang 5 & 312 & 313 & 625 & 22,49 & 23,27 & 22,88 \\
\hline Jumlah & $\mathbf{1 3 8 7}$ & $\mathbf{1 3 4 5}$ & $\mathbf{2 7 3 2}$ & $\mathbf{1 0 0}$ & $\mathbf{1 0 0}$ & $\mathbf{1 0 0}$ \\
\hline
\end{tabular}

Sumber : Kantor Kecamatan Kawangkoan Barat, 2017

Tabel 2. Jumlah Dan Persentase Petani Responden Menurut Kelompok Umur

\begin{tabular}{cccc}
\hline No & Umur (Tahun) & Jumlah Responden (Orang) & Persentase (\%) \\
\hline 1. & $20-35$ & 6 & 30 \\
2. & $36-50$ & 12 & 60 \\
3. & $51-65$ & 1 & 5 \\
5. & $>66$ & 1 & 5 \\
\hline & Jumlah & $\mathbf{2 0}$ & $\mathbf{1 0 0}$ \\
\hline
\end{tabular}

Sumber data : Diolah dari data primer, 2017

Tabel 3. Jumlah Dan Presentase Responden Menurut Tingkat Pendidikan.

\begin{tabular}{cccc}
\hline No & $\begin{array}{c}\text { Umur } \\
\text { (Tahun) }\end{array}$ & Jumlah Responden (Orang) & Persentase (\%) \\
\hline 1. & SD & 9 & 45 \\
2. & SMP & 7 & 35 \\
3. & SMA & 4 & 20 \\
\hline & Jumlah & $\mathbf{2 0}$ & $\mathbf{1 0 0}$ \\
\hline
\end{tabular}

Sumber data : diolah dari data primer, 2017

Tabel 4. Jam Kerja Wanita Dalam Usahatani Kacang Tanah

\begin{tabular}{|c|c|c|c|c|c|}
\hline \multirow[b]{2}{*}{ No } & \multirow[b]{2}{*}{ Jenis Pekerjaan } & \multirow{2}{*}{$\begin{array}{l}\text { Jumlah Jam / } \\
\text { periode tanam }\end{array}$} & \multirow{2}{*}{$\begin{array}{c}\text { rata-rata jam / } \\
\text { periode / responden }\end{array}$} & \multicolumn{2}{|c|}{ Persentase $(\%)$} \\
\hline & & & & jumlah jam & $\begin{array}{c}\text { Rata - rata } \\
\text { jam }\end{array}$ \\
\hline 1 & Seleksi Benih & 60 & 3 & 2,65 & 2,65 \\
\hline 2 & Pengolahan tanah & 88 & 4,4 & 3,88 & 3,88 \\
\hline 3 & Penanaman & 108 & 5,4 & 4,76 & 4,76 \\
\hline 4 & Penyiangan & 940 & 47 & 41,45 & 41,45 \\
\hline 5 & $\begin{array}{l}\text { Pengendalian } \\
\text { hama dan penyakit }\end{array}$ & 0 & 0 & 0,00 & 0,00 \\
\hline 6 & Pemupukan & 0 & 0 & 0,00 & 0,00 \\
\hline 7 & Panen & 380 & 19 & 16,75 & 16,75 \\
\hline 8 & Pasca panen & 356 & 17,8 & 15,70 & 15,70 \\
\hline 9 & Pemasaran & 336 & 16,8 & 14,81 & 14,81 \\
\hline & Jumlah & 2268 & 113,4 & 100 & 100 \\
\hline
\end{tabular}

Sumber data : diolah dari data primer, 2017 


\section{KESIMPULAN DAN SARAN}

\section{Kesimpulan}

Peran tenaga kerja wanita dilihat dari curahan waktu kerja wanita dalam usahatani kacang tanah yang tertinggi yaitu pada kegiatan penyiangan, kedua panen, ketiga pasca panen, keempat pemasaran, kelima penanaman, keenam pengolahan tanah, ketujuh seleksi benih, pada pemupukan dan pengendalian hama penyakit wanita tidak berperan.

\section{Saran}

Diharapkan pada tenaga kerja wanita dalam usahatani kacang tanah Desa Kanonang Kecamatan Kawangkoan barat pada kegiatan panen, pasca panen, dan pemasaran lebih ditingkatkan.

\section{DAFTAR PUSTAKA}

Adisarwanto, T, 2000. Meningkatkan Produksi Kacang Tanah di Lahan Sawah dan Lahan Kering, Penebar Swadaya, Jakarta.

Bachrein, S., I. Ishaq, dan v.w Rufaidah, 2000. Peranan Wanita Dalam Pengembangan Usahatani di Jawa Barat ( Studi kasus: Kecamatan Cikelet, Garut). Jurnal JP2TP3 (1).

Baruwadi, Mahludin. 2006. Ekonomi Rumah Tangga. UNG Pres Gorontalo.

Baso, T. 2016. kontribusi wanita tani dalam kegiatan usahatani kacang tanah di desa kota wuna kecamatan tongkuno kabupaten muna. Skripsi Universitas Halu oleo. Kendari

Ciboro, M.A, 2008. Respon Beberapa Varietas Kacang Tanah ( Arhacis hipogea). Terhadap Pemakaian Mikoriza pada Berbagai Cara Pengolahan Tanah. Universitas Sumatera Utara Medan.

Damatun, M, 2016. peran tenaga kerja wanita dalam usahatani hortikultura di kelurahan wailan tomohon utara kota tomohon. Skripsi Universitas Sam Ratulangi, Manado.

Daniel. 2002. Pengantar Ekonomi Pertanian. Bumi Aksara: Jakarta.
Elizabeth, R, 2008, Wanita Tani Dalam Pencapaian Ketahanan Pangan Rumah Tangga di Pedesaan, Iptek Tanaman Pangan Vol. 3 No. 1.

Hartono, Sunaryati, 2000. Ratifikasi Konvensi Perserikatan Bangsa - Bangsa Tentang Penghapusan Segala Bentuk Diskriminasi Terhadap Wanita dan Undang - Undang Hak Asasi Manusia. Direktoral Jendral Pendidikan Tinggi Departemen Pendidikan Nasional Jakarta.

Komariyah. 2003. Profil Wanita Buruh Tani Dalam Usaha Meningkatkan Kesehatan, Desa Wonorejo, Kecamatan Srengat, Kabupaten Blitar. ITB: Bandung. http://www.jiptum.org.ac.id

Kompas. 2011. Pertanian Serap 42,27 Juta Tenaga Kerja. Available at http://bisnis keuangan.kompas.com/read/2011/07/30/ 01373438/Pertanian.Serap.42,27.Juta.Te naga.Kerja (diakses pada tanggal 20 Juni 2013, 23:29:24).

Mahdalia, A Kontribusi Curahan Waktu Kerja Perempuan Terhadap Total Curahan Waktu Kerja Pada Usaha Peternakan Sapi Potong di Pedesaan. Makasar.

Sukesi, K. MS. 2002. Hubungan Kerja Dan Dinamika Hubungan Gender Dalam Sistem Pengusahaan Tebu Rakyat. Lembaga Penerbitan Fakultas Pertanian Universitas Brawijaya. Malang.

Sugihastuti. 2000. Wanita Dimata Wanita. Yayasan Adikarya IKAPI Dan The Lord Foundation: Yogyakarta.

Suratiyah, K. 2006. Ilmu Usahatani. Penebar Swadaya. Jakarta.

Soekartawi, (2002).Prinsip Dasar Ekonomi Pertanian.Jakarta, Raja Grafindo Persada.

Sumarsono, S. 2009. Teori dan Kebijakan Publik Ekonomi Sumber Daya Manusia. Graha Ilmu. Yogyakarta.

Zannatos, Zafiris. 2004. Pertumbuhan Adjusment Dan Pasar Tenaga Kerja, Efek Pada wanita Pekerja Keras Disampaikan Pada Konferensi Internasional ke-4 Assoviation Untuk Femisi, konomi Universite, Efrancoise, tabelis, Tours perancis, 5-7 Juli. 